\section{Color Changes and Antioxidant Content of Vine and Postharvest- ripened Tomato Fruits}

\author{
Zoltán Pék and Lajos Helyes ${ }^{1}$ \\ Institute of Horticulture and Technology, Szent István University, Páter K. st. 1., \\ Gödöllö, 2103, Hungary
}

Andrea Lugasi
National Institute for Food and Nutrition Science, Gyáli ut 3/a, H-1097
Budapest, Hungary

Additional index words. tomato, antioxidants, color, postharvest

\begin{abstract}
Tomato fruit ripening is a complex, genetically programmed process that culminates in dramatic changes in texture, color, flavor, and aroma of the fruit flesh. The characteristic pigmentation of red ripe tomato fruit is the result of the de novo synthesis of carotenoids, mainly lycopene and $\beta$-carotene, which are associated with the change in fruit color from green to red as chloroplasts are transformed to chromoplasts. The aim of this study was to examine the effect of ripening conditions on color development and antioxidant content. Detached tomato fruit stored at 15 and $30{ }^{\circ} \mathrm{C}$ and vine-ripened fruits were studied to characterize the ripening process by Hue $\left(^{\circ}\right.$ ) index (CIELab color system), which is strongly influenced by the circumstances of ripening. Total polyphenols, ascorbic acid, and lycopene content of tomato fruits were analyzed at the end of the experiment. Changes in the color of fruit stored at $15^{\circ} \mathrm{C}$ and vine-ripened fruit showed significantly higher $a^{*}$ compared with fruit stored at $30{ }^{\circ} \mathrm{C}$. Storage temperature influenced positively ascorbic acid and negatively lycopene content, whereas total polyphenols did not show differences among the different ripening conditions.
\end{abstract}

Tomato is a significant food crop with more than 126 million tons harvested in the world in 2007 (FAOSTAT Crop Production Tomato, 2008) and characterized by high consumption, year-round availability, and significant health benefits. It contains high levels of antioxidants (Abushita et al., 2000), which are important in the prevention of many cancer types and cardiovascular diseases (Takeoka et al., 2001). Color is one of the most important quality components of tomato fruits. The amount of predominant carotenoid lycopene, which causes red coloration of fruits, is characterized well by a* parameter. $\beta$-carotene is an orange colorant of fruits, in which the parameter is measurable by b* in the CIELab color system (Sacks and Francis, 2001). The ripening process of tomatoes is well characterized by the color evolution of fruit surface (Hertog et al., 2007). Chlorophyll breaks down and carotenoids, mostly lycopene, accumulate during ripening (Brandt et al., 2006).

There is a general belief that the quality of vine-ripened tomatoes is better than that of fruit ripened off the vine. Analytically, vineripened tomatoes contain more lycopene, $\beta$-carotene, soluble and total solids, and had

Received for publication 25 Nov. 2009. Accepted for publication $28 \mathrm{Jan} .2010$.

This study was partially funded by TECH-09-A32009-0230, USOK2009 project.

${ }^{1}$ To whom reprint requests should be addressed; e-mail helyes.lajos@mkk.szie.hu.
Model 1230; Atago Co. Ltd., Tokyo, Japan) according to the Hungarian Standard (MSZ EN 12143, 1998).

Acid content of fruits was determined according to a Hungarian Standard and expressed as mg citric acid in $100 \mathrm{~g}$ fresh weight (MSZ EN 750, 1998).

Ascorbic acid content was measured according to a Hungarian Standard (MSZ EN 14130, 2003). The compound was quantified by Reverse Phase (RP) high-performance liquid chromatography (HPLC) on a Lichrosper 100 RP18 end-capped column (Merck Kft., Budapest, Hungary) $(5 \mu \mathrm{m}, 250 \times 4.0 \mathrm{~mm})$ using potassium-dihydrogenphosphate/N-cetyl$\mathrm{N}, \mathrm{N}, \mathrm{N}$-trimethyl-ammonium-bromide in methanol $(92 / 8 \mathrm{v} / \mathrm{v})$ as a mobile phase and ultraviolet detection at $265 \mathrm{~nm}$. The characteristics of the determination are as follows: column temperature $35{ }^{\circ} \mathrm{C}$, flow rate $0.7 \mathrm{~mL} \cdot \mathrm{min}^{-1}$, volume of injection $80 \mu \mathrm{L}$, and running time $14 \mathrm{~min}$. The HPLC system used for ascorbic acid analysis consisted of Perkin Elmer Co. (Norwalk, CT) Series 200 equipment with a Series 200 highprecision pump combined with a Series 200 Autosampler, a Series 200 HPLC Photo Diode Array Detector, and an IRIS Spectral Processing System.

Carbohydrate content was measured after an acidic hydrolysis with $\mathrm{HCl}$ at $65^{\circ} \mathrm{C}$ during 5 min by the classical Schoorl method (COMMISSION DIRECTIVE 79/796/EEC, 1979).

Total polyphenols were analyzed with the Folin-Denis method according to the AOAC official protocol 952.03 (AOAC, 1990).

Lycopene was extracted from the tomato juice with a mixture of n-hexane, methanol, and acetone (2:1:1) containing BHT. Optical density of the hexane extract was measured at $502 \mathrm{~nm}$ by a Perkin Elmer Lambda 3B ultraviolet spectrophotometer (Perkin Elmer Co.) (Sadler et al., 1990). Lycopene concentrations were calculated by applying the molecular extinction coefficient of 158500 (Merck\&Co., 1989). All parameters measured are referred to fresh weight of fruits.

The results were expressed as the average \pm SD at $P=0.05$. The statistical analysis was carried out by the Student $t$ test using the Statistica 9 software (Statsoft Inc., Tulsa, OK).

\section{Results and Discussion}

Figure 1 shows the evolution of CIELab color parameter $\mathrm{a}^{*}$ and $\mathrm{b}^{*}$, which represents well-colorful carotenoid content of tomato fruits. However, the evolution of the red fruit color (a*) was more rapid at $30{ }^{\circ} \mathrm{C}$ than at $15{ }^{\circ} \mathrm{C}$ or on the vine. Color changes in fruit stored at $15{ }^{\circ} \mathrm{C}$ and developed on the vine were different from those at $30{ }^{\circ} \mathrm{C}$ because lycopene, which is the main source of the red color of tomato, is not synthesized above $30^{\circ} \mathrm{C}$. In this temperature range, only $\beta$-carotene is produced, which has a ceiling temperature of $38^{\circ} \mathrm{C}$ (Brandt et al., 2006).

CIELab $\mathrm{a}^{*} / \mathrm{b}^{*}$ or Hue index is the most commonly used parameter to indicate the color development of ripening tomato fruit. Table 1 shows CIELab color parameters of 
vine and postharvest ripened tomato fruits at the end of the ripening process. The Hue value of fruit stored at $30^{\circ} \mathrm{C}$ was significantly higher (less red) than of those ripened at $15^{\circ} \mathrm{C}$ or on the vine.

Figure 2 shows the evolution of the Hue value of tomatoes during ripening. Temperature and the method of ripening greatly affect the ripening processes of tomatoes. Hertog et al. (2007) reported similar temperature effects in their study on color changes of detached tomatoes at different constant temperatures.

Soluble solids ( ${ }^{\circ}$ Brix), reducing sugars, titratable acidity, ascorbic acid, total polyphenols, and lycopene content were also evaluated (Table 2). For soluble solids ( ${ }^{\circ}$ Brix) and reducing sugars, only slight differences could be ascribed to ripening conditions. Total polyphenol content did not differ among treatments and ranged between 28 and $32 \mathrm{mg} / 100 \mathrm{~g}$, which are acceptable in greenhouse-grown tomatoes. Fruits stored at $15{ }^{\circ} \mathrm{C}$ had the lowest ascorbic acid content $(14.2 \mathrm{mg} / 100 \mathrm{~g})$. In fruit stored at $30{ }^{\circ} \mathrm{C}$ and in vine-ripened fruit, it was 15.2 and $17.5 \mathrm{mg}$ / $100 \mathrm{~g}$, respectively. Hence, a significant difference between on- and off-vine ripened tomatoes has been established. Higher temperature seems to be favorable for ascorbic acid synthesis. In addition, solar exposure is probably required for further ascorbic acid accumulation, but this was ambiguous during a longer ripening process (Wold et al., 2004). Riga et al. (2008) have studied vine-ripened tomato and established that temperature had a stronger influence on tomato antioxidants than photosynthetically active radiation. Growers could obtain tomatoes of similar color by postharvest ripening than that provided on the vine by natural sunlight.

Fruit samples revealed considerable treatment-specific differences (more than $50 \%)$ in lycopene content. For the red color parameters, storage at $30{ }^{\circ} \mathrm{C}$ resulted in the lowest lycopene content $(2.1 \mathrm{mg} / 100 \mathrm{~g})$ and vine-ripened tomatoes contained the highest concentration $(4.5 \mathrm{mg} / 100 \mathrm{~g})$. Initially, lycopene synthesis was accelerated at $30{ }^{\circ} \mathrm{C}$ and during the first $5 \mathrm{~d}$, the red coloration was more rapid in fruit of this treatment. Nevertheless, the optimal temperature for lycopene synthesis is 16 to $22{ }^{\circ} \mathrm{C}$, whereas the ceiling temperature is 30 to $32{ }^{\circ} \mathrm{C}$ (Dumas et al., 2003), so at the end of the ripening process, fruits stored at $15{ }^{\circ} \mathrm{C}$ and vine-ripe contained statistically higher lycopene content. This agrees with the finding of Helyes et al. (2007) that found the fruit surface temperature has a dominant role in lycopene synthesis in tomatoes.

Results of our study have implications for improvement of tomato for lycopene and red coloration. In conclusion, tomato fruits subjected to elevated air temperatures increased orange colorants ( $\beta$-carotene) and decreased the content of lycopene in the tomato fruits.

The mechanism of on-vine and detached tomato fruit ripening appears to be different and requires more study to accurately describe these differences.

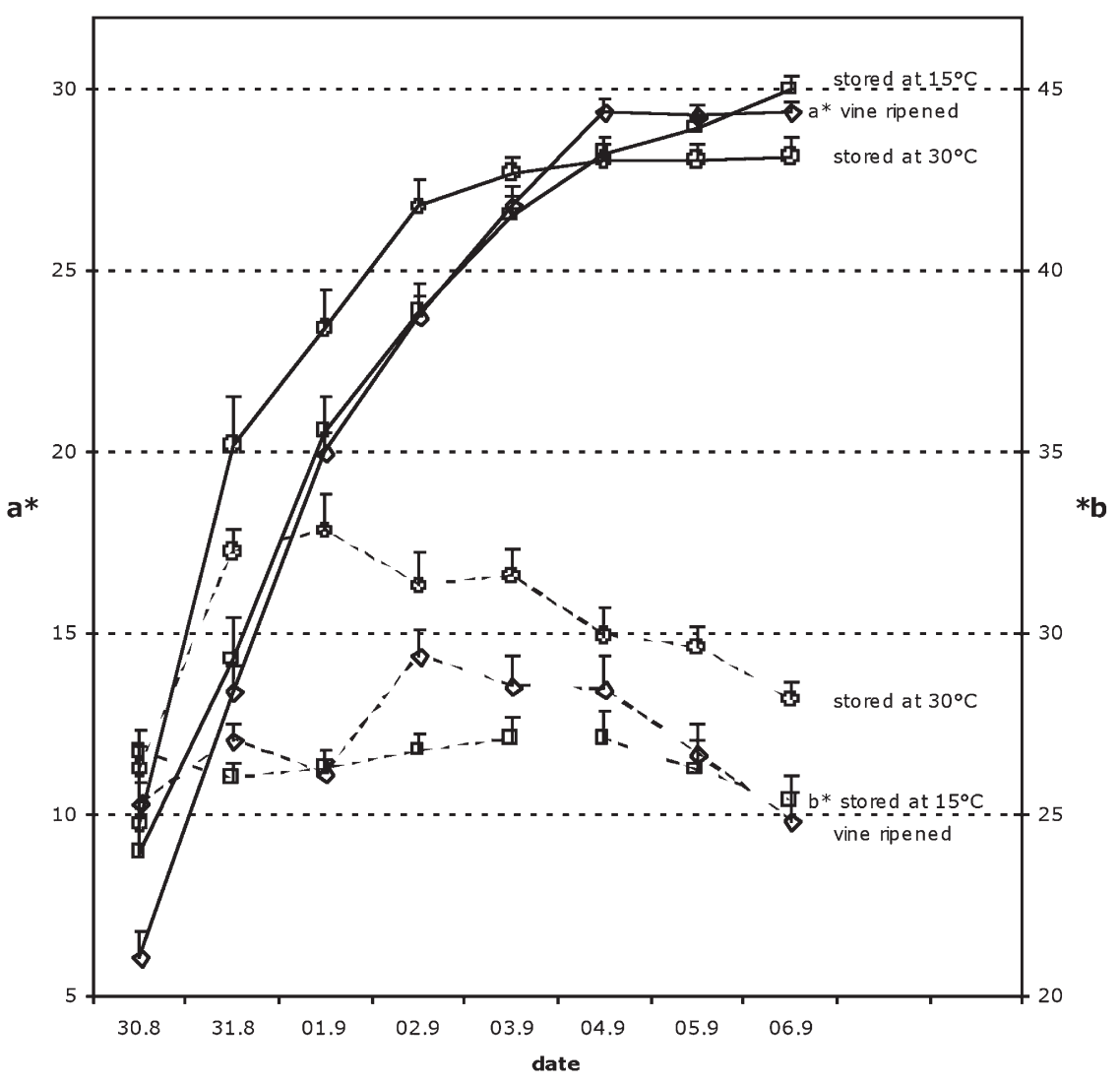

Fig. 1. Evolution of CIELab color parameters $\left(a^{*}, b^{*}\right)$ of tomato fruits during the ripening period. Vertical bars represent the significant differences at $P=0.05(\mathrm{n}=16)$.

Table 1. CIELab color parameters of vine and postharvest ripened tomato (cv. Lemance $F_{1}$ ) fruits at the end of the ripening process $(n=4 ; \pm S D)$.

\begin{tabular}{lcccc}
\hline & $\mathrm{L}^{* \mathrm{z}}$ & $\mathrm{a}^{*}$ & $\mathrm{~b}^{*}$ & Hue \\
\hline Vine-ripened & $41.2 \pm 0.78^{\mathrm{a}}$ & $29.4 \pm 0.52^{\mathrm{a}}$ & $24.9 \pm 1.62^{\mathrm{a}}$ & $40.0 \pm 1.74^{\mathrm{a}}$ \\
Storage $\left(15^{\circ} \mathrm{C}\right)$ & $43.1 \pm 1.06^{\mathrm{b}}$ & $30.0 \pm 0.76^{\mathrm{a}}$ & $25.4 \pm 1.48^{\mathrm{a}}$ & $40.1 \pm 1.70^{\mathrm{a}}$ \\
Storage $\left(30^{\circ} \mathrm{C}\right)$ & $44.0 \pm 0.94^{\mathrm{b}}$ & $28.2 \pm 0.92^{\mathrm{b}}$ & $28.2 \pm 1.02^{\mathrm{b}}$ & $45.0 \pm 1.24^{\mathrm{b}}$ \\
\hline
\end{tabular}

${ }^{2}$ Data in the same column bearing the same superscript letter are not significant at $P=0.05$.

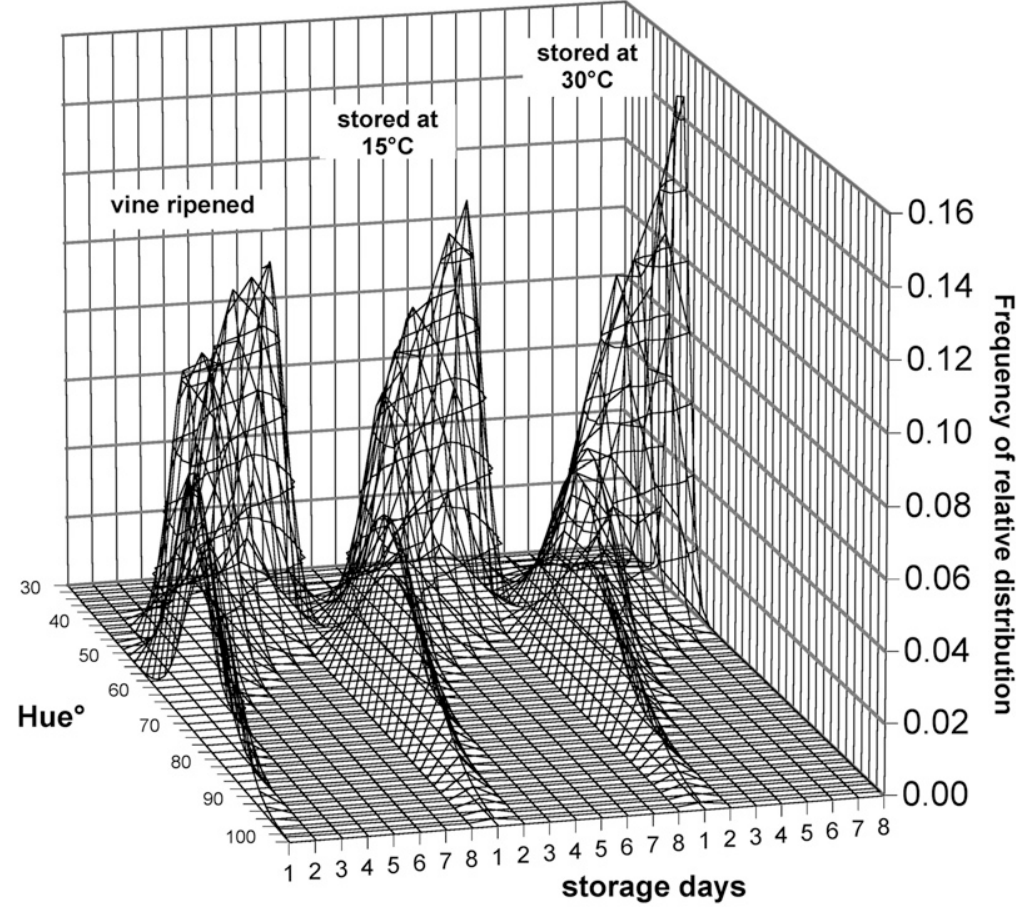

Fig. 2. Frequency distribution of Hue color parameter during the ripening process of vine and postharvest ripened tomato fruits. 
Table 2. Components of vine and postharvest ripened tomato (cv. Lemance $\mathrm{F}_{1}$ ) fruits at the end of the ripening process $(n=4 ; \pm S D)$.

\begin{tabular}{lcccccc}
\hline & ${ }^{\circ}$ Brix $^{\mathrm{z}, \mathrm{y}}$ & Sugars $(\%)$ & $\begin{array}{c}\text { Organic } \\
\text { acids }(\%)\end{array}$ & $\begin{array}{c}\text { Ascorbic acid } \\
(\mathrm{mg} / 100 \mathrm{~g})\end{array}$ & $\begin{array}{c}\text { Total polyphenols } \\
(\mathrm{mg} / 100 \mathrm{~g})\end{array}$ & $\begin{array}{c}\text { Lycopene } \\
(\mathrm{mg} / 100 \mathrm{~g})\end{array}$ \\
\hline Vine-ripened & $4.3 \pm 0.15$ & $2.3 \pm 0.35$ & $4.0 \pm 0.47$ & $17.5 \pm 2.19^{\mathrm{a}}$ & $29.4 \pm 2.12$ & $4.5 \pm 1.40^{\mathrm{a}}$ \\
Storage $\left(15^{\circ} \mathrm{C}\right)$ & $4.5 \pm 0.09$ & $2.3 \pm 0.20$ & $4.1 \pm 0.10$ & $14.2 \pm 1.48^{\mathrm{b}}$ & $31.5 \pm 3.22$ & $3.9 \pm 0.70^{\mathrm{a}}$ \\
Storage $\left(30^{\circ} \mathrm{C}\right)$ & $4.4 \pm 0.06$ & $2.1 \pm 0.17$ & $4.2 \pm 0.19$ & $15.2 \pm 3.07^{\mathrm{a}}$ & $27.7 \pm 1.68$ & $2.1 \pm 0.64^{\mathrm{b}}$ \\
\hline
\end{tabular}

${ }^{\mathrm{z}}$ Data in the same column bearing the same superscript letter are not significant at $P=0.05$.

${ }^{y}$ Data were recorded on a fresh weight basis.

\section{Literature Cited}

Abushita, A.A., H.G. Daood, and P.A. Biacs. 2000. Change in carotenoids and antioxidant vitamins in tomato as a function of varietal and technological factors. J. Agr. Food Chem. 6:2075-2081.

AOAC. 1990. AOAC official protocol 952.03. Official method of analysis. 15th ed. Association of Official Analytical Chemists, Arlington, VA.

Arias, R., T.C. Lee, D. Specca, and H. Janes. 2000. Quality comparison of hydroponic tomatoes (Lycopersicon esculentum) ripened on and off vine. J. Food Sci. 65:545-548.

Brandt, S., Z. Pék, É. Barna, A. Lugasi, and L. Helyes. 2006. Lycopene content and colour of ripening tomatoes as affected by environmental conditions. J. Sci. Food Agr. 86:568-572.

COMMISSION DIRECTIVE 79/796/EEC. 1979. Community methods of analysis for testing certain sugars intended for human consumption. Offic. J. L, 239:24-52.

Dumas, Y., M. Dadomo, G. Di Lucca, and P. Grolier. 2003. Effects of environmental factors content of tomatoes. J. Sci. Food Agr. 83 369-382.

Food and Agriculture Organization of the United Nations. 2009. Crop Production Tomato FAOSTAT. 1. Nov. 2009.<http://faostat.fao.org/ site/567/DesktopDefault.aspx?PageID=567\#ancor>.

Helyes, L., A. Lugasi, and Z. Pék. 2007. Effect of natural light on surface temperature and lycopene content of vine ripened tomato fruit. Can. J. Plant Sci. 87:927-929.

Hertog, M.L.A.T.M., J. Lammertyn, N. Scheerlinck, and B.M. Nicolai. 2007. The impact of biological variation on postharvest behaviour: The case of dynamic temperature conditions. Postharvest Biol. Technol. 43:183-192.

Merck\&Co. 1989. Merck index. 11th Ed. Merck \& Co., Inc, Rahway, NJ.

MSZ EN 12143. 1998. Fruit and vegetable juices. Estimation of dry matter content. Refractometric method (Gyümölcs- és zöldséglevek. Az oldható szárazanyagtartalom becslése. Refrak-
MSZ EN 750. 1998. Determining of titratable acidity of fruit and vegetable products (Gyümölcs- és zöldségtermékek titrálható savtartalmának meghatározása).

MSZ EN 14130. 2003. Foodstuffs. Determination of vitamin $\mathrm{C}$ by HPLC (Élelmiszerek. Cvitamin meghatározása HPLC módszerrel).

Riga, P., M. Anza, and C. Garbisu. 2008. Tomato quality is more dependent on temperature than on photosynthetically active radiation. J. Sci. Food Agr. 88:158-166.

Sacks, E.J. and D.M. Francis. 2001. Genetic and environmental variation for tomato flesh color in a population of modern breeding lines. J. Amer. Soc. Hort. Sci. 126:221-226. tometriás módszer).
Sadler, G., J. Davies, and D. Dezman. 1990. Rapid extraction of lycopene and $\beta$-carotene from reconstituted tomato paste and pink grapefruit homogenates. J. Food Sci. 55:1460-1461.

Takeoka, G.R., L. Dao, S. Flessa, D.M.W. Gillesp, T. Jewell, B. Huebner, D. Bertow, and S.E. Ebeller. 2001. Processing effects on lycopene content and antioxidant activity of tomatoes. J. Agr. Food Chem. 49:3713-3717.

Wold, A.B., H.J. Rosenfeld, K. Holte, H. Baugerød, R. Blomhoff, and K. Haffner. 2004. Color of post-harvest ripened and vine ripened tomatoes (Lycopersicon esculentum Mill.) as related to total antioxidant capacity and chemical composition. Int. J. Food Sci. Technol. 39:295302. eggplant, peppers and others, p. 291-312. In: Yamaguchi, M. (ed.). World vegetables. AVI Book, New York, NY.
Yamaguchi, M. 1983. Solanaceous fruits: Tomato, 